\title{
PLANAR SCINTIGRAPHY IMAGE DE-NOISING USING COIFLET WAVELET
}

\section{REDUKSI NOISE PADA CITRA SKINTIGRAFI PLANAR MENGGUNAKAN COIFLET WAVELET}

\author{
Ayu Jati Puspitasari, Ika Cismila Ningsih, Muhammad Sulthonur Ridwan, Halim Hamadi \\ Polytechnic Institute of Nuclear Technology, \\ Indonesian National Nuclear Energy Agency (BATAN) \\ Jalan Babarsari PO BOX 6101 YKBB, Sleman, Yogyakarta \\ E-mail:ayu.puspitasari@batan.go.id
}

Received 17 March 2021, Received in revised form 10 June 2021, Accepted 14 June 2021

\begin{abstract}
PLANAR SCINTIGRAPHY IMAGE DE-NOISING USING COIFLET WAVELET. The planar scintigraphic image usually has a poor resolution and contains noise. This noise can be removed using the coiflet wavelet with Coif5 coefficient so that the image quality gets better. The coiflet wavelet method is a noise reduction method based on frequency analysis. The planar scintigraphy image is the reconstructed image of the gamma radiation count data (phantom with the Cs-137 source in it). The original image is $15 \times 15$ pixels. Before the de-noising process, the image went through an interpolation process, which is to increase pixel count of the image. The original image was resized to $70 \times 70,480 \times 480$, and 1200×1200 pixels. After the interpolated images were denoised with coiflet wavelet, the image quality is measured based on Mean Square Error (MSE) and Peak Signal to Noise Ratio (PSNR) parameters. The resulting images are quite good, with MSE and PSNR values being close to zero and more than $60 \mathrm{~dB}$, respectively. The smaller the MSE and the bigger the PSNR are, the better the image quality is. In this study, the result shows that the 1200×1200 pixels image has the best quality. It means that the process of increasing pixel count has a good effect on the de-noising process, especially if the original image has a low resolution.
\end{abstract}

Keywords: planar scintigraphy image, de-noising, coiflet wavelet, MSE, PSNR.

\section{ABSTRAK}

REDUKSI NOISE PADA CITRA SKINTIGRAFI PLANAR MENGGUNAKAN COIFLET WAVELET. Citra skintigrafi planar biasanya memiliki resolusi yang kurang baik dan mengandung noise. Noise ini dapat dihilangkan menggunakan coiflet wavelet dengan koefisien Coif5 sehingga kualitas gambar menjadi lebih baik. Metode coiflet wavelet ini merupakan metode pengurangan noise berdasarkan analisis frekuensi. Citra skintigrafi planar adalah citra rekonstruksi dari data cacahan radiasi gamma (phantom dengan sumber Cs-137 di dalamnya). Citra asli berukuran $15 \times 15$ piksel. Sebelum proses de-noising, citra melalui proses interpolasi, yaitu memperbesar resolusi citra. Citra asli diperbesar menjadi 70×70, 480×480, dan 1200×1200 piksel. Setelah menghilangkan noise dengan coiflet wavelet, kualitas citra diukur berdasarkan parameter MSE dan PSNR. Citra yang dihasilkan menggunakan Coif5 ini cukup baik, dengan nilai MSE mendekati nol dan nilai PSNR lebih dari 60 dB. Semakin kecil MSE dan semakin besar PSNR, semakin baik kualitas gambarnya. Pada penelitian ini didapatkan hasil bahwa citra berukuran 1200×1200 piksel memiliki kualitas terbaik. Hal ini mengartikan bahwa proses peningkatan jumlah pixel berpengaruh baik pada proses de-noising, terutama jika citra asli memiliki resolusi yang rendah.

Kata Kunci: citra skintigrafi planar, pengurangan noise, coiflet wavelet, MSE, PSNR.

\section{INTRODUCTION}

The application of nuclear technology in the medical area, including diagnostic and therapeutic, uses image
processing technology [1]. The diagnostic examination uses an external radiation source and generates
transmission processes, with CT-Scan (Computed Tomography Scanner) being one of such equipment. In nuclear
medicine, the internal radiation source is used to generate emission events. Nuclear medicine utilizes an Anger
scintillation camera or gamma camera [2,3]. The types of the gamma camera, such as planar and SPECT (Single 
Photon Emission Computed Tomography), have an essential difference, that is planar type will only be capable of displaying a 2D image, while SPECT (Single Photon Emission Computed Tomography) will generate 3D image [4], [5]. Gamma camera applies scintigraphy technique.

Planar scintigraphy images the distribution of radioactive material in a $2 \mathrm{D}$ image. This is mostly used for whole-body screening for tumors, metastatic tumors, and particularly bone [6]. A suitable radioactive material can be concentrated on a specific target organ after being compounded with another chemical into radiopharmaceutical, a chemical compound that contains radioactive atoms in its structure. It is used in the field of nuclear medicine for diagnosis or therapy. After applying radiopharmaceutical to the patient, the target organ will be imaged using a gamma camera that can detect gamma emission [7].

The quality of some of the produced images is good, but some are affected by noise (white noise, shot noise, salt and pepper noise, etc.), so the quality is degraded. The main source of noise is the random distribution detected by the gamma camera. The noise density level is generally very high compared to other imaging modalities. High noise levels will blur contrast and reduce image quality, resulting in an inaccurate diagnosis [8]. Several techniques were applied to enhance the quality of these images, with the image de-noising technique being one of the effective tools to enhance the image quality [9].

De-noising is an essential albeit complicated process in medical imaging [10]. In nuclear medicine imaging, scintigraphic images are commonly used to indicate the condition of some organs, despite their poor resolution. The quality depends both on the size and the layout of collimator holes, while the image resolution depends on the size of the holes and the detector sensitivity. In a scintigraphic image, the pixel value represents the radiation counting by the detector and contains a discrete value. These discrete values follow a distribution and this distribution is responsible for the presence of noise in the images [10-12]. So, image processing is needed for noise removal or reduction [14].

The benefits of image processing are identifying invisible objects, reducing noise, sharpening and restoring images [15]. Image processing can be applied using some techniques, such as image representation, preprocessing, enhancement, analysis, and compression. Image enhancement functions to remove noise, sharpen, or brighten images. Image enhancement techniques can be divided into spatial and frequency domain methods $[15,16]$.

Image de-noising using wavelets shows the capability of fulfilling the compromise between smoothing and keeping important features [11]. Noise reduction in nuclear medicine can be proposed using wavelet transform [17], [18]. Noise in scintigraphic images can be corrected using several methods, one of which is the wavelet method, with the benefit being easy images comparison with different resolutions [9], [19]. Wavelet decomposition is quick and easy to compute. The amount of data in the image is not reduced when using wavelet transforms [9]. What distinguishes wavelet transforms from other techniques is the less distortion in the spectral characteristics of the noise-removed image [20].

Wavelet analysis is a technique to transform an array of $\mathrm{N}$ numbers from their actual numerical values to an array of $\mathrm{N}$ wavelet coefficients. Each wavelet coefficient signifies the proximity of the fit (or correlation) between the wavelet function at a particular size and a particular location within the data array [20]. Wavelet operates by dividing the image into certain parts with different frequencies, then each part of the image is passed by a signal or wavelet wave. These waves have different shapes and characteristics depending on the wavelet family used. There are several types of wavelet families in discrete wavelet transform (DWT), such as haar wavelets, coiflet wavelets, etc. The wavelet family has several forms of various wavelet functions and their respective scale functions [21]. Discrete Wavelet Transform affects the resulting PSNR value, one of the parameters for measuring image quality [22].

The coiflet wavelet is a type of the wavelet family (short name coif) where for the order of $\mathrm{N}$, it is written as coifN. The length of the coiflet wavelet filter is $6 \mathrm{~N}$, where the order of the mother wavelet function and the scaling functions are $2 \mathrm{~N}$ and $2 \mathrm{~N}-1$, respectively [21]. The coiflet wavelet family (coif5) provides better performance compared to other wavelet families in improving image quality, especially images with high noise densities [23]. Figure 1 shows the Coiflet Wavelet family. 


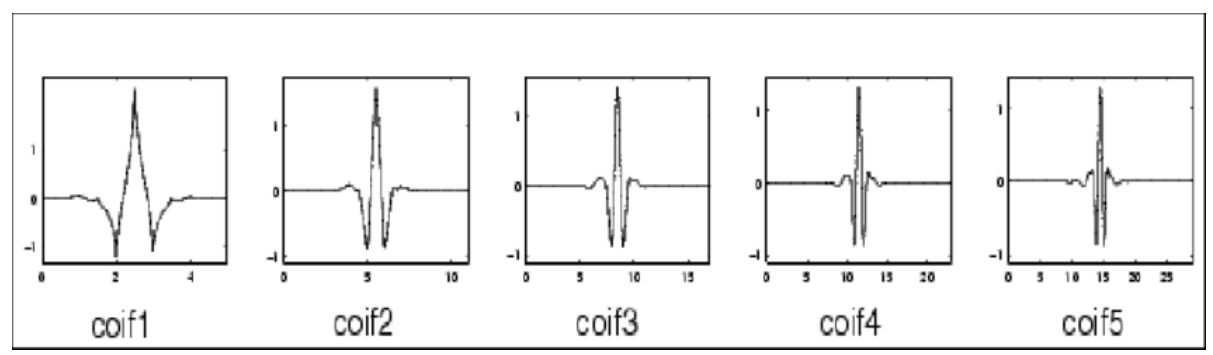

Figure 1. Coiflet wavelet family [24].

To determine the amount of noise lost and the quality of image reconstruction, several parameters can be evaluated, namely the mean square error (MSE) and peak signal to noise ratio (PSNR). MSE is the most common parameter of image quality measurement. MSE measures the mean of the squared cumulative errors between the resulting and original images, values closer to zero are better $[8,21]$. PSNR is a quantification of the reconstructed signal quality. It is defined as the ratio between the maximum possible power value of a signal and the strength of the noise affecting the image [9]. To calculate PSNR, we have to calculate MSE first [25]. These are the following equations, Eq. (1) and (2).

$$
\begin{aligned}
& M S E=\frac{1}{m \times n} \sum_{i=0}^{m-1} \sum_{j=0}^{n-1}[I(i, j)-K(i, j)]^{2} \\
& P S N R=10 \log _{10}\left(\frac{M A X_{I}^{2}}{M S E}\right)=20 \log _{10}\left(\frac{M A X_{I}}{\sqrt{M S E}}\right)=20 \log _{10}\left(M A X_{I}\right)-10 \log _{10}(M S E)
\end{aligned}
$$

Where $I(i, j)$ is the original image, $K(i, j)$ is the reconstructed image, and $\mathrm{m}, \mathrm{n}$ are the pixels of the image. $M A X_{I}$ is the maximum pixel value possible from the image and MSE is the Mean Square Error [9].

This study aims to reduce noise in planar scintigraphy images using coiflet wavelet. This scintigraphy image is obtained from gamma radiation measurements using the Nuclear Instrument Module (NIM). The reconstructed image quality was evaluated based on MSE and PSNR parameters.

\section{METHODOLOGY}

The planar scintigraphy image is the reconstruction of the gamma radiation counting matrix. The source Cs137 has a diameter of $25 \mathrm{~mm}$ and an area of $490.63 \mathrm{~mm}^{2}$. It is placed in a $7 \times 7 \mathrm{~cm}$ acrylic phantom with three different positions $(40,30 ; 20,50$; and 13.5,13.5; in $\mathrm{mm})$ based on the coordinate shown in Figure 2. Data collection was done every $5 \mathrm{~mm}$, so we have 15 points of measurement on each axis.

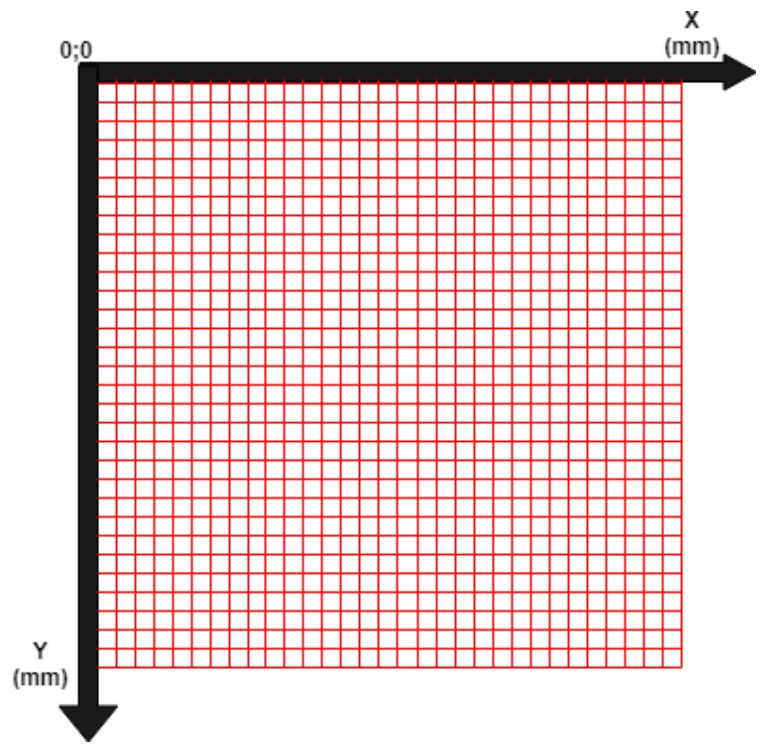

Figure 2. Data collection coordinate. 
Gamma radiation is counted using a $\mathrm{Nal}(\mathrm{TI})$ scintillation detector which has been given a lead $(\mathrm{Pb})$ collimator. The diameter of the detector is 2 inches. A $3 \mathrm{~mm}$ thick collimator will limit the catchment area to $2 \mathrm{~mm}$. The collimator is used to focus the beam and to limit the catching area of the detector. The results of radiation detection by the scintillation detector (including Photomultiplier Tube, PMT) will be processed with amplifier and Single-Channel Analyzer (SCA) modules; these modules are NIM (Nuclear Instrumentation Module) standard (Figure 3).

The radiation counting results are compiled in a matrix to form an original image measuring $15 \times 15$ pixels. Figure 4 is the result of the original image from the Cs- 137 phantom with a $7 \times 7 \mathrm{~cm}$ area which is turned into a $15 \times 15$ matrix so that it produces an original image with a resolution of $15 \times 15$ pixels. The flowchart of image reconstruction and enhancement (de-noising) using the Python language is shown in Figure 5.

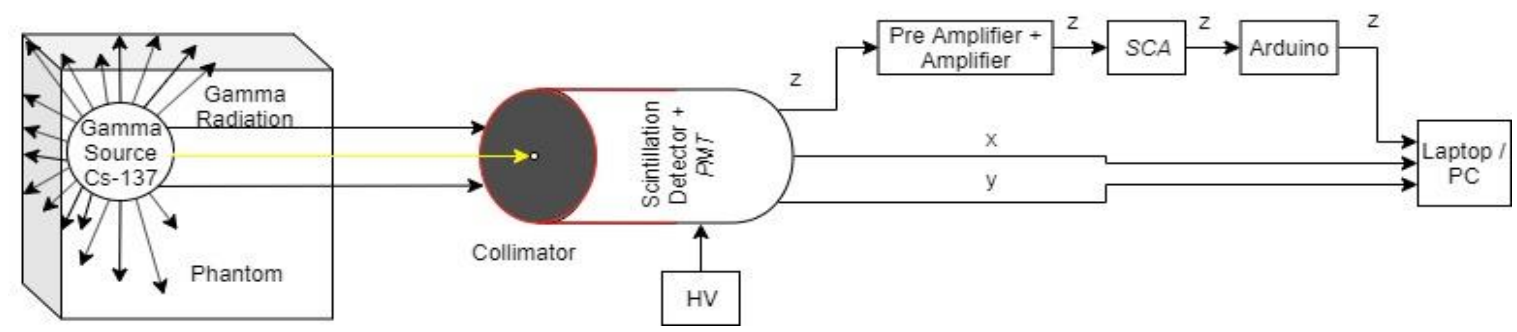

Figure 3. Block diagram of radiation count measurement.

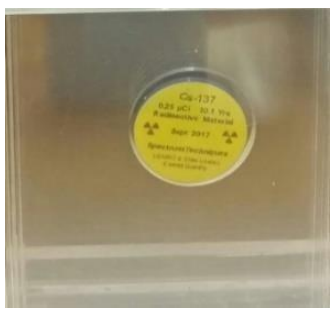

(a)

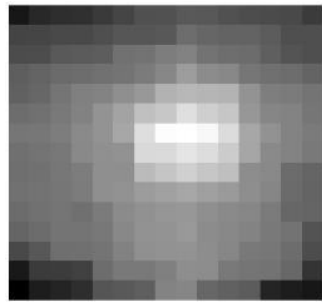

(d)

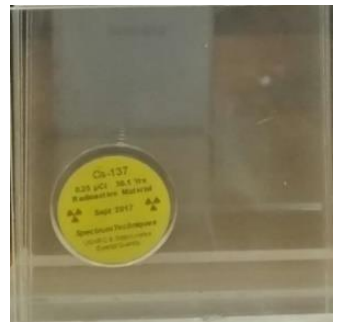

(b)

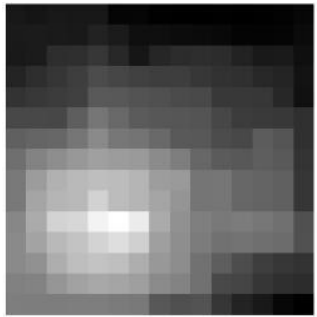

(e)

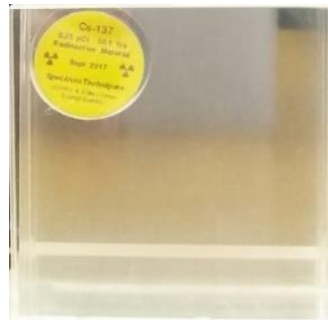

(c)

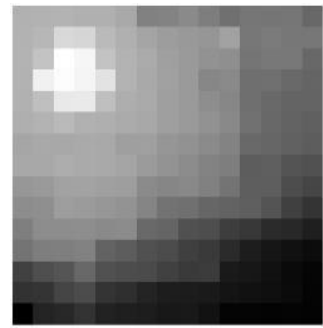

(f)

Figure 4. Cs-137 in the phantom: (a) position 1 (40,30); (b) position 2 (20,50); (c) position 3 (13.50,13.50); and original image: (d) position 1 (40,30); (e) position 2 (20,50); (f) position $3(13.50,13.50)$.
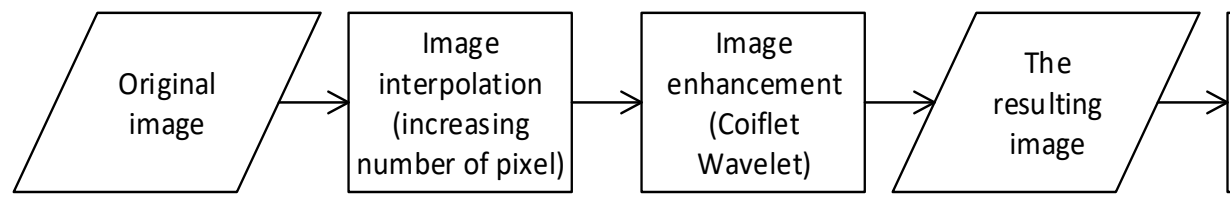

MSE and PSNR

Evaluation

Figure 5. De-noising image process' flowchart. 
The radiation count matrix is reconstructed into an original image, then the original image is interpolated. Image interpolation is a method used to resize or distort an image. In this case, a nearest-neighbor interpolation is used to change the image resolution by increasing the number of pixels. The original image is resized to $70 \times 70$, $480 \times 480$, and $1200 \times 1200$ pixels. Variations of pixel count were used to determine whether there is an effect between image resolution and image quality after improving image quality process using the coiflet wavelet method.

In this study, the pywavelet package was used to apply the coiflet wavelet method. There are three stages: decomposing to divide the image into different frequencies, de-noising to reduce noise, and reconstructing the image again used the inverse discrete wavelet transform. The following is the result of the implementation program code for the coiflet wavelet method.

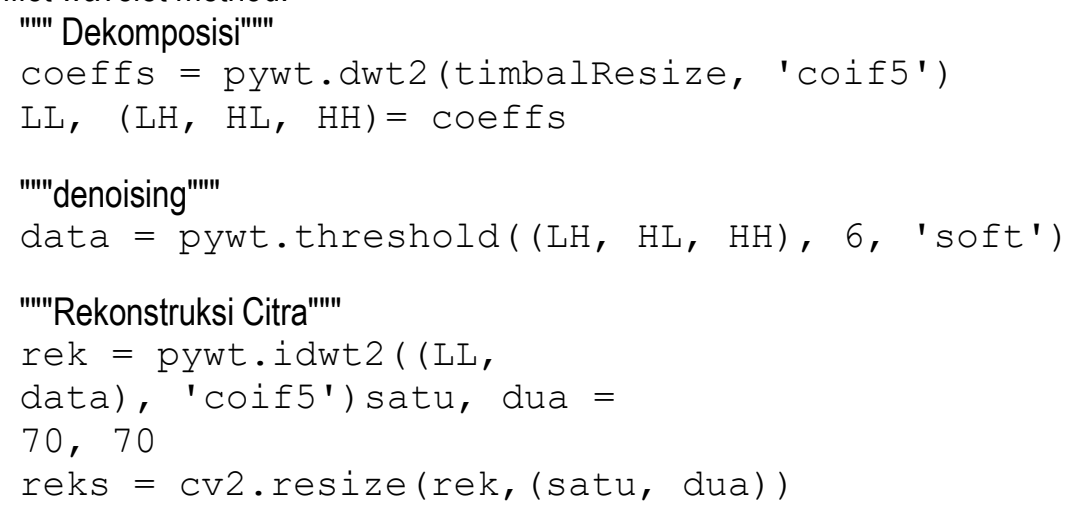

The decomposition of the coiflet wavelet is done using the command "coeffs = pywt.dwt2 (timbalResize, 'coif $5^{\prime}$ ". After that, the resized image is separated according to its frequency. The decomposition is first level, so the image divided into four frequency parts using the command " $\mathrm{LL}, \quad(\mathrm{LH}, \mathrm{HL}$, $\mathrm{HH})=$ coeffs", resulting in 4 parts of the image, namely the image with low-low frequency (LL), low-high frequency $(\mathrm{LH})$, high-low frequency $(\mathrm{HL})$, and high-high frequency $(\mathrm{HH})$. $\mathrm{LL}$ is called the approximation coefficient, which can store information from the image. $\mathrm{LH}, \mathrm{HL}$, and $\mathrm{HH}$ are referred to as the detail coefficients. The denoising process on the image is only carried out on the detail coefficient. The part or layout of the approximation coefficients and detailed coefficients in a 2D array can be seen in Figure 6 .

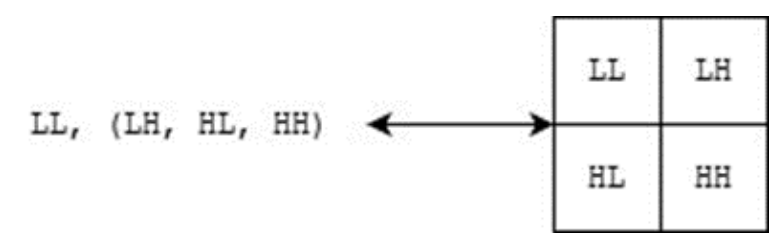

Figure 6. Approximate Coefficient and Detail Coefficient in 2D Arrays.

After the decomposition process, de-noising was carried out. The command used in the de-noising process is "data = pywt.threshold $((\mathrm{LH}, \mathrm{HL}, \mathrm{HH}), 6$, 'soft' $)$ ". De-noising is only done on the image detail coefficient, by performing soft thresholding on that coefficient. The thresholding level is generated automaticaly. The last process is reconstructing the image again with the command "rek = pywt.idwt2 ( (LL, data), 'coif5')".

\section{RESULTS AND DISCUSSIONS}

Before de-noising, the original images of $15 \times 15$ pixels from $7 \times 7 \mathrm{~cm}$ phantom were interpolated to increase pixel count using nearest-neighbor interpolation. The pixel count increased to $70 \times 70,480 \times 480$, and $1200 \times 1200$ pixels. The results are shown in Table 1.

After increasing number of pixel in Table 1, the de-noising process was carried out using a coiflet wavelet. The results of the image after the de-noising process shown in Table 2. 
Table 1. Increase the number of pixels.

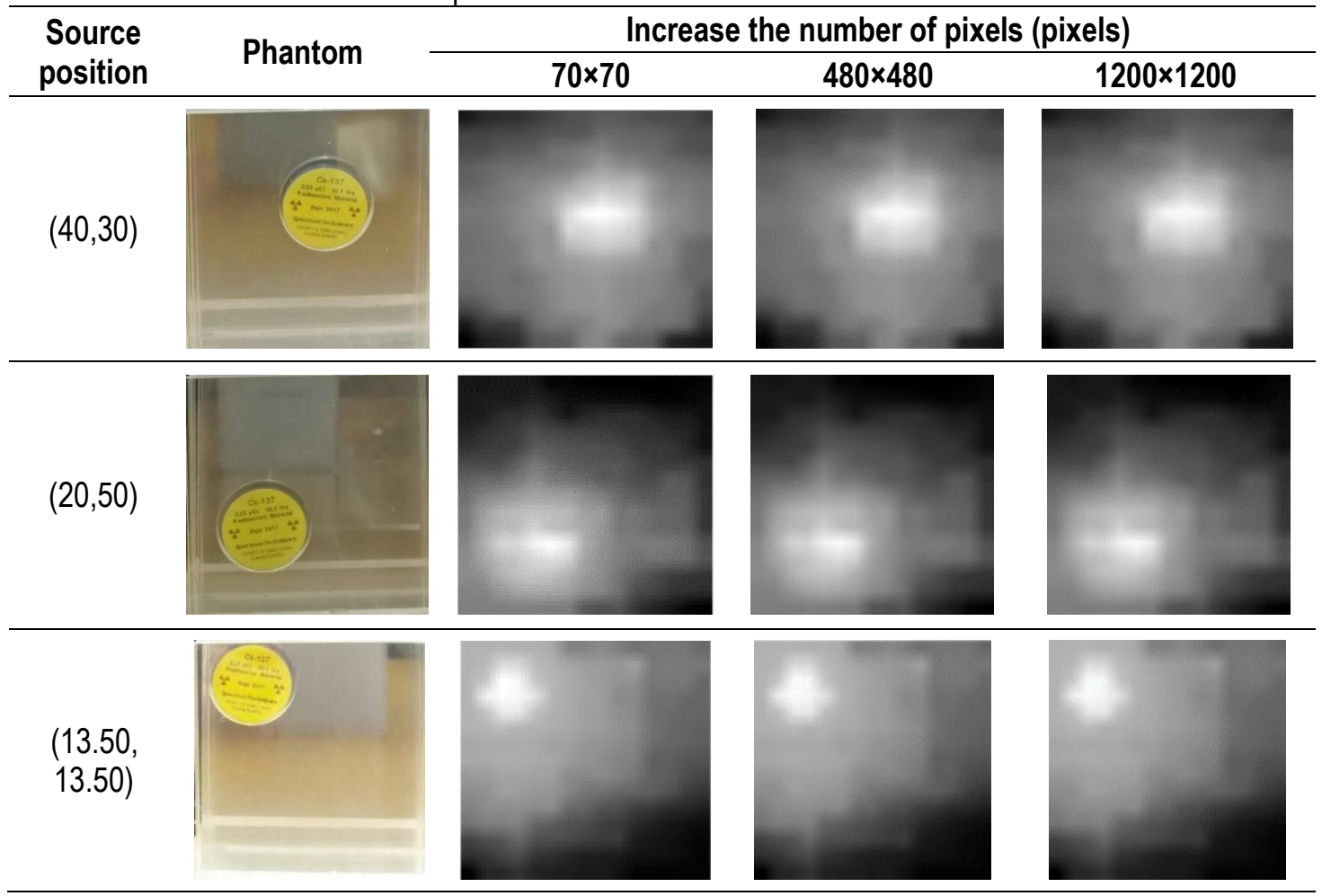

Table 2. The resulting images of de-noising process.

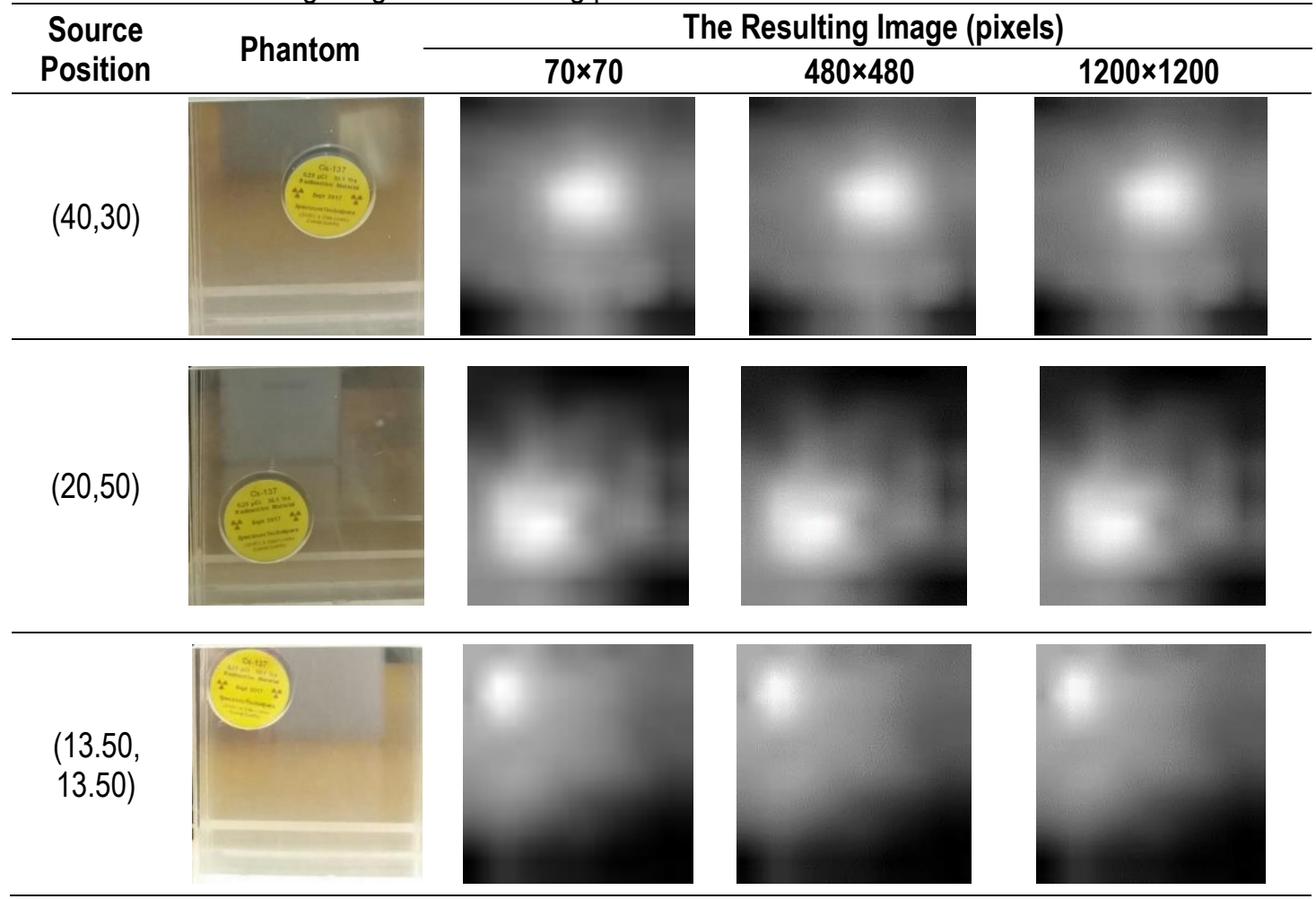


Table 3. MSE and PSNR calculation.

\begin{tabular}{|c|c|c|c|c|}
\hline No & $\begin{array}{l}\text { Source } \\
\text { Position }\end{array}$ & Image resolution (pixels) & MSE & PSNR (dB) \\
\hline \multirow[t]{3}{*}{$\overline{1}$} & \multirow[t]{3}{*}{$(40,30)$} & $70 \times 70$ & 0.02 & 64.66 \\
\hline & & $480 \times 480$ & $4.39 \times 10^{-5}$ & 91.70 \\
\hline & & $1200 \times 1200$ & $2.81 \times 10^{-6}$ & 103.64 \\
\hline \multirow[t]{3}{*}{2} & \multirow[t]{3}{*}{$(20,50)$} & $70 \times 70$ & 0.02 & 64.38 \\
\hline & & $480 \times 480$ & $4.59 \times 10^{-5}$ & 91.50 \\
\hline & & $1200 \times 1200$ & $2.49 \times 10^{-6}$ & 103.44 \\
\hline \multirow[t]{3}{*}{3} & \multirow[t]{3}{*}{$(13.50,13.50)$} & $70 \times 70$ & 0.01 & 66.17 \\
\hline & & $480 \times 480$ & $3.00 \times 10^{-5}$ & 93.35 \\
\hline & & $1200 \times 1200$ & $1.92 \times 10^{-6}$ & 105.29 \\
\hline \multirow{3}{*}{\multicolumn{2}{|c|}{$\overline{\text { Average }}$}} & $70 \times 70$ & 0.02 & 65.07 \\
\hline & & $480 \times 480$ & $3.80 \times 10^{-5}$ & 92.18 \\
\hline & & $1200 \times 1200$ & $2.43 \times 10^{-6}$ & 104.12 \\
\hline
\end{tabular}

The denoised images in Table 2 are grayscale images with three image resolution variations at each position of the radioisotope source in the phantom. The images of varying resolutions cannot be distinguished visually. So, it is necessary to calculate the image quality parameters, namely MSE and PSNR.

The calculation of the value of MSE (Mean Square Error) and PSNR (Peak Signal to Noise Ratio) was used to test image quality after noise reduction was carried out. The calculation of the MSE and PSNR values uses equations (1) and (2).

Discrete wavelet transform is used to filter the noise so that the signal or image quality is better. Coiflet wavelet can reduce high-density noise. There are 5 types of coiflet families, from coif1 to coif5, each of which has a different value of the coefficient. This wavelet coiflet decomposes the scintigraphic image into low $(\mathrm{L})$ and high $(H)$ frequency coefficients. By the first level of decomposition, the image will be divided into $L L, H L, L H$, and $H H$. $\mathrm{LL}$ is the set for low-frequency components, while $\mathrm{HL}, \mathrm{LH}$, and $\mathrm{HH}$ are set for high-frequency coefficients. $\mathrm{HL}$ is the set of horizontal detail coefficients, $\mathrm{LH}$ is the vertical detail coefficient, and $\mathrm{HH}$ is the diagonal detail coefficient. Coif5 used in this study is proven to be able to reduce noise as indicated by its PSNR value, with a PSNR value of more than $60 \mathrm{~dB}$. This also confirms the result of Rohima's research (2020) that coif5 produces the highest PSNR (56.9861 dB) compared to coefficients in other Coiflet families [26].

MSE cannot be equated with human visual perception. MSE shows the difference between the reconstructed vector image and the reference image. A low MSE value indicates two vectors are equal [27]. MSE is also referred to as noise power, a small value in MSE indicates that the noise in the image is small. The results of the MSE and PSNR calculations presented in Table 4 are quite good. Fatma Makhlouf et al (2013) had done similar research where several methods (one of them was wavelet transform) were used to de-noise planar scintigraphy images. Wavelet transformation is used to reduce several levels of Poisson noise of a scintigraphy image, with average PSNR results of $32.21 \mathrm{~dB}$ [19]. Thus, all of the results that were produced here are better, since the PSNR values are higher for all of the images. Although the image quality cannot be distinguished visually, the results of noise reduction using this wavelet coiflet can be said to be good. An image is said to have a good quality if the PSNR value is above $40 \mathrm{~dB}$ [28]. All images, with various test resolution variations, produce PSNR values above $40 \mathrm{~dB}$.

The greater the PSNR value is, the better the image quality becomes, while the smaller the MSE value is, the less noisy the image will be [25], [29], [30]. These can be seen from the $1200 \times 1200$ pixels image. The image with the smallest MSE average is the $1200 \times 1200$ pixels image too. So, the image with the best image quality is that image.

The bigger the image resolution is, the better the resulting image quality. This is consistent with how the coiflet wavelet method works. This method works by filtering unwanted frequencies in the image, after the image 
was divided into four parts, each having different frequencies. If the image resolution that is included in the coiflet wavelet is small, then the image will be further divided into four smaller parts. Thus, during the de-noising process, there is less information that can be processed. This is why a small resolution image will produce a poor quality image and vice versa.

Pixel count affects the quality of the resulting image based on the MSE and PSNR values. The larger the image resolution is, the smaller the MSE value is, indicating that there is less noise in the image. In addition, a high PSNR value means that the image quality is excellent. This means that the interpolation process or the increase of the pixel count a good effect on the de-noising process afterward. Interpolation should be done, especially on images with low resolution, if a good quality image is desired. But, the increase in image resolution should not be too large so as not to affect its spatial resolution.

\section{CONCLUSION}

The enhancement process of this planar scintigraphy image was carried frequency analysis, namely the coiflet wavelet with Coif5 coefficient. Before the de-noising process, the image went through an interpolation process to increase the image resolution. The original image, which has a resolution of $15 \times 15$ pixels, resized to $70 \times 70,480 \times 480$, and $1200 \times 1200$ pixels. After de-noising with coiflet wavelet was carried, the image quality is measured based on MSE and PSNR parameters. The resulting images are quite good, with MSE values are close to zero and PSNR values are more than $60 \mathrm{~dB}$. This means that the noise in planar scintigraphy images can be reduced using the coif5 coefficient of the Coiflet wavelet. It is interesting to see that the interpolation process can help the de-noising process. Pixel count affects the resulting MSE and PSNR values. The smaller the MSE is and the bigger the PSNR is, the better the image quality becomes. In this study, the result shows that the $1200 \times 1200$ pixels image has the best quality. It means that the process of increasing pixel count has a good effect on the denoising process, especially if the original image has a low resolution. However, it is recommended that the increase of image resolution should not be too large so as not to affect its spatial resolution.

\section{ACKNOWLEDGEMENT}

Authors wishing to acknowledge assistance or encouragement from Electronics Instrumentation, Polytechnic Institute of Nuclear Technology.

\section{REFERENCES}

[1] Y. Sasaki and K. Kusakabe, "Nuclear medicine for diagnosis and treatment," IAEA Off. Public Inf. Commun., vol. 17, no. 1, pp. 7-8, 2017.

[2] F. Kharfi, "Principles and Applications of Nuclear Medical Imaging: A Survey on Recent Developments," Imaging Radioanal. Tech. Interdiscip. Res. - Fundam. Cut. Edge Appl., no. March 2013, 2013.

[3] Y. Wang, "Nuclear Medicine : Physics and Imaging Methods ( SPECT and PET )," New York, 2017.

[4] D. H. Skuldt, Nuclear medicine. Vienn: International Atomic Energy Agency, 2014.

[5] T. Lewellen, "The Scintillation Camera: Planar and SPECT List of Nuclear Medicine 'Single Photon' Radionuclides." Department of Radiology, University of Washington, 2007.

[6] N. B. Smith and A. Webb, Introduction to Medical Imaging, 1st editio. Cambridge, England: Cambridge University Press, 2010.

[7] J. L. Prince and J. M. Links, Medical Imaging Signals and Systems, 2nd ed. Pearson, 2014.

[8] "Image quality and quality control in diagnostic nuclear medicine," International Atomic Energy Agency, 2021. https://www.iaea.org/resources/rpop/health-professionals/nuclear-medicine/diagnostic-nuclearmedicine/image-quality-and-quality-control\#4 [Accessed Apr. 26, 2021].

[9] A. Dixit and S. Majumdar, "COMPARATIVE ANALYSIS OF COIFLET AND DAUBECHIES WAVELETS USING GLOBAL THRESHOLD FOR IMAGE DENOISING," Int. J. Adv. Eng. Technol., no. November, pp. 2247-2252, 2013.

[10] S. R, K. G, and J. P. L, "Image Denoising using new digital pulse mode neural network," Int. J. Eng. Trends Technol., vol. 4, no. 2, pp. 114-118, 2013. 
[11] K. Nawres, H. Kamel, and E. Noureddine, "Image denoising using Wavelets : A powerful tool to overcome some limitations in nuclear imaging," in 2006 2nd International Conference on Information \& Communication Technologies, 2006, pp. 1114-1118.

[12] K. B. Khan, A. A. Khaliq, M. Shahid, and H. Ullah, "Poisson noise reduction in scintigraphic images using Gradient Adaptive Trimmed Mean filter," in 2016 International Conference on Intelligent Systems Engineering, ICISE 2016, 2016, pp. 301-305.

[13] P. Hannequin and J. Mas, "Statistical and heuristic image noise extraction (SHINE): A new method for processing Poisson noise in scintigraphic images," Phys. Med. Biol., vol. 47, no. 24, pp. 4329-4344, 2002.

[14] H. K. Khaung Tin, "Removal of Noise by Median Filtering in Image Processing," 6th Parallel Soft Comput. (PSC 2011), no. December, pp. 1-3, 2011.

[15] K. Sumithra, S. Buvana, and R. Somasundaram, "A Survey on Various Types of Image Processing Technique," Int. J. Eng. Res., vol. V4, no. 03, pp. 399-403, 2015.

[16] P. Ravi and A. Ashokkumar, "Analysis of Various Image Processing Techniques," Int. J. Adv. Netw. Appl., vol. 8, no. 5, pp. 86-89, 2017.

[17] K. Ogawa, M. Sakata, and Y. Li, "Adaptive noise reduction of scintigrams with a wavelet transform," Int. J. Biomed. Imaging, vol. 2012, pp. 22-27, 2012.

[18] D. R. Newlin and C. Seldev Christopher, "Medical image denoising using different techniques," Int. J. Sci. Technol. Res., vol. 9, no. 3, pp. 1061-1066, 2020.

[19] F. Makhlouf, H. Besbes, N. Khalifa, C. Ben Amar, and B. Solaiman, "Planar Scintigraphic Images Denoising," Open J. Med. Imaging, vol. 03, no. 04, pp. 116-124, 2013.

[20] I. Chaabouni, W. Fourati, S. Med, and M. S. Bouhlel, "Comparative study of different wavelets for image compressed by ISOM," in ICSPT 2013, 2013, no. March.

[21] Ç. Uyulan and T. T. Erguzel, "COMPARISON OF WAVELET FAMILIES FOR MENTAL TASK," J. Neurobehav. Sci., vol. 3, no. 2, 2016.

[22] S. Zufar, "Perbaikan Kualitas Citra dengan Metode Discrete Wavelet Transform dan Metode Retinex," Universitas Jember, 2018.

[23] S. Tena, "PERBAIKAN KUALITAS CITRA BERWARNA DENGAN METODE DISCRETE WAVELET TRANSFORM (DWT)," in Seminar Nasional Sains dan Teknik, 2012, vol. 2012, no. Sainstek, pp. 230-236.

[24] M. Nabih, "Time-Frequency analysis of Different types of signals," Ain Shams University, 2016.

[25] M. Manju, P. Abarna, and S. Yamini, "Peak Signal to Noise Ratio \& Mean Square Error calculation for various Images using the lossless Image compression in CCSDS algorithm," in International Journal of Pure and Applied Mathematics, 2018, vol. 119, no. 12, pp. 14471-14477.

[26] Rohima and M. Barkah Akbar, "Wavelet Analysis and Comparison from Coiflet Family on Image Compression," in 2020 8th International Conference on Cyber and IT Service Management, CITSM 2020, 2020, pp. 4-8.

[27] A. K. Moorthy, Z. Wang, and A. C. Bovik, "Visual Perception and Quality Assessment," in Optical and Digital Image Processing: Fundamentals and Applications, G. Cristobal, P. Schelkens, and H. Thienpont, Eds. New Jersey: John Wiley \& Sons, 2011, pp. 419-439.

[28] I. U. W. Mulyono, A. Susanto, M. R. F. Febrian, and G. A. Rosyida, "A Combination of Hill Cipher and LSB for Image Security," Sci. J. Informatics, vol. 7, no. 1, pp. 155-165, 2020.

[29] D. Asamoah, E. Ofori, S. Opoku, and J. Danso, "Measuring the Performance of Image Contrast Enhancement Technique," Int. J. Comput. Appl., vol. 181, no. 22, pp. 6-13, 2018.

[30] R. Kumar, G. Sharma, and V. Sanduja, "A Real Time Approach to Compare PSNR and MSE Value of Different Original Images and Noise ( Salt and Pepper, Speckle, Gaussian) Added Images," Int. J. Latest Technol. Eng. Manag. Appl. Sci., vol. 7, no. 1, pp. 43-46, 2018. 